\title{
Relationship modelling between moisture content of flour and variables of two-cycle drying process of cassava flourusing pneumatic dryer
}

\author{
Yus Witdarko ${ }^{1}$, Philipus Betaubun², and Jayadi ${ }^{3}$ \\ ${ }^{1}$ Agricultural Engineering, Faculty of Agriculture, Musamus University, Merauke-Indonesia \\ ${ }^{2}$ Civil Engineering, Faculty of Engineering, Musamus University, Merauke-Indonesia \\ ${ }^{3}$ Electro Engineering, Faculty of Engineering, Musamus University, Merauke-Indonesia
}

\begin{abstract}
Moisturecontent (MC) is the most important variable in evaluating material drying performance, so the ability to predict MC in drying process is really important. This research aims to formulate the mathematic relationship between drying process variable pneumatically and moisture content of cassava flour in drying process 1 and 2 by applying dimensional analysis. In this research, there has been a design of pneumatic drying equipment and test using various treatments such as input capacity, drying air temperature, and drying air velocity. Based on the data analysis, the relationship between $\mathrm{MC}$ and drying process variables are as follow:
\end{abstract}

Drying cycle 1:

Drying cycle 2:

$$
M C=(5,794287 E-22) .\left(\frac{\rho_{p r} \cdot D_{p r}^{3}}{Q_{i} \cdot \theta}\right)^{1,4085}\left(\frac{T_{u}}{T_{b o}}\right)^{-2,2504}\left(\frac{V_{u} \cdot \theta}{D_{p r}}\right)^{5,863}
$$

$$
M C=(2,36831 E-10) .\left(\frac{\rho_{p r} D_{p r}^{3}}{Q_{i} \cdot \theta}\right)^{1,059}\left(\frac{T_{u}}{T_{b o}}\right)^{-4,808}\left(\frac{V_{u} \cdot \theta}{D_{p r}}\right)^{3,709}
$$

The equations have determination coefficient value 0.85 , so it has big possibility to use it as alternative to predict moisture content of dried flour.

Keywords: cassava flour, pneumatic drying, dimensional analysis, moisture content

\section{Introduction}

Cassava flour is a starch produced by industries that commonly have applied mechanical drying system. It is necessary to have some scientific information to develop drying process of cassava flour, considering that the drying process is a step which needs big and expensive energy (Desrosier, 2008)[4].

In some cassava or starch industries, pneumatic drying method has been used. In this method, wet cassava flour is put inside a vertical dryer pipe line in certain length, and then dry flour and air are separated using cyclone that is put at the end of the dryer pipe line.

Various variables of drying process operations, dryer machine, or grated material of cassava flour that has been dried are really important at determining the final quality of the flour drying result. In the material drying process, the main variable used to evaluate drying process performance is moisture content of the drying result.

In the flour drying, National Standardize Board 2012 or BSN requires that the maximum final moisture content is $12 \%$ wb (SNI 01-2997-1996). Meanwhile, according to Afrianti (2000) [1], the safe amount of moisture content in foodstuff is $11 \% \mathrm{wb}$ because fungus may grow in substrates of food of which minimum content water is $12 \% \mathrm{wb}$, while bacteria and yeast may grow in more than moisture content of $30 \% \mathrm{wb}$. In the low moisture content, it is possible to store the flour because the flour is not easy to moldy or to be attacked by insects. Therefore, it is important to guarantee that the drying process is conducted well so it can generate a way to relate the variables of drying process to moisture content resulted from drying process. Zare et al (2012)[8] has conducted drying process for canola seeds in various drying air humidity, that is, $0.0005-0.02 \mathrm{~kg} / \mathrm{kg}$ with stable temperature of $45^{\circ} \mathrm{C}$. The research result shows mathematic relationship between ratio (MR) with 
drying time ( $\mathrm{t}$ ), and drying constant (a,b, $\mathrm{k}_{1}$, and $\mathrm{k}_{2}$ ), experiment data (exp) in the form of the following equation:

$$
M R=a \exp -k_{1} t+b \exp -k_{2} t
$$

Where, $\mathrm{a}=2,834-0,563 \operatorname{Ln}(\mathrm{T}) 8,752 \mathrm{H} ; \mathrm{k}_{1}=0,079-$ $0,018 \operatorname{Ln}(\mathrm{T}) \quad 0,011 \mathrm{H} ; \mathrm{b}=-1,83+0,5621 \operatorname{Ln}(\mathrm{T})-$ $8,978 \mathrm{H} ; \mathrm{k}_{2}=0,542+0,188 \operatorname{Ln}(\mathrm{T})-1,38 \mathrm{H}$

Goula and Adamopoulos (2005) [5] have done drying experiment to tomato powder in various drying air temperature and air flow rate. The research result shows mathematic relationship between moisture content $(\mathrm{M})$ and drying air temperature $\left(\mathrm{T}_{\text {inlet }}\right)$ and drying air rate $\left(Q_{a}, Q_{c}\right)$, in the form of this equation:

$$
\begin{aligned}
& M=124-186 \cdot T_{\text {inlet }}-0,681 \cdot Q_{a}+ \\
& 0,00115 \cdot Q_{c}+0,00692 \cdot T_{\text {inlet }}^{2}-0,00735 \cdot Q_{a}^{2}- \\
& 0,000003 \cdot Q_{c}^{2}-0,00213 \cdot T_{\text {inlet }} \cdot Q_{a}
\end{aligned}
$$

Bunyawanichakul et al (2007)[3] has done pneumatic drying to rice seeds in various diameter of dryer pipe $(0.102-0.203 \mathrm{~m})$, input capacity of the seeds $(0.5-1 \mathrm{~kg} / \mathrm{s})$, and drying air velocity $(15-23$ $\mathrm{m} / \mathrm{c}$ ) in stable temperature $110^{\circ} \mathrm{C}$. The research result shows mathematic relationship between moisture content $(\mathrm{MC})$ and relative humidity $(\mathrm{RH})$ and rice seeds temperature $\left(T_{p}\right)$ written in the following equation:

$$
M=\frac{1}{100}\left[\frac{\ln (1-R H)}{-3,146 \times 10^{-6} T_{p}}\right]^{\frac{1}{2,464}}
$$

To find out mathematic equation that relates MC and drying process variables of cassava flour, it is necessary to know the drying result in its drying process condition, so it can be used to predict moisture content of cassava flour within the drying process.

Dimensional analysis has simple steps, but it gives a lot of benefits for researches to design equipment in small scale and cheap cost which is possible to use in laboratory. Furthermore, by using this dimensional analysis, designing process of pneumatic drying machine can be carried out meticulously. The aim of this research is to relate $\mathrm{MC}$ of flour and some variables of pneumatic drying process using dimensional analysis method. The mathematic relationship will ease the machine designer in constructing pneumatic drying machine or drying machine operator in generating moisture content of dried flour in order to meet the standard of $\mathrm{MC}$ determined by SNI.

\section{Research Method}

Dimensional analysis is a means to find out quantitative relationship of flour product, drying machine, and drying process. In this research, to find out mathematic relationship between moisture content or MCof dried flour and some drying process variables, there have been selected some variables which are predicted to have certain relationship. Table 1 shows some independent variables that possibly have relationship with moisture content or MC of flour

\begin{tabular}{|c|c|c|c|}
\hline Variable name & Symbol & $\begin{array}{c}\text { Uni } \\
\mathrm{t}\end{array}$ & Dimension \\
\hline \multicolumn{4}{|l|}{$\begin{array}{l}\text { Independent } \\
\text { variables }\end{array}$} \\
\hline $\begin{array}{l}\text { a. Density of } \\
\text { particle }\end{array}$ & $\rho_{\mathrm{pr}}$ & $\begin{array}{l}\mathrm{kg} / \\
\mathrm{m}^{3}\end{array}$ & $\mathrm{ML}^{-3}$ \\
\hline $\begin{array}{l}\text { b. Capacity of } \\
\text { material } \\
\text { input }\end{array}$ & $\overline{Q_{i}}$ & $\mathrm{~kg} / \mathrm{s}$ & $\mathrm{MT}^{-1}$ \\
\hline $\begin{array}{ll}\text { c. } & \text { Initial } \\
\text { material } \\
\text { temperature }\end{array}$ & $\mathrm{T}_{\mathrm{bo}}$ & ${ }^{\circ} \mathrm{C}$ & $\mathrm{O}$ \\
\hline $\begin{array}{l}\text { d. } \begin{array}{l}\text { Drying air } \\
\text { temperature }\end{array} \\
\end{array}$ & $\mathrm{T}_{\mathrm{u}}$ & ${ }^{\circ} \mathrm{C}$ & $\mathrm{O}$ \\
\hline $\begin{array}{l}\text { e. Diameter of } \\
\text { particle }\end{array}$ & $\mathrm{D}_{\mathrm{pr}}$ & $\mathrm{m}$ & $\mathrm{L}$ \\
\hline f. Drying time & $\theta$ & $\mathrm{s}$ & $\mathrm{T}$ \\
\hline $\begin{array}{l}\text { g. Drying time } \\
\text { velocity }\end{array}$ & $\mathrm{V}_{\mathrm{u}}$ & $\mathrm{m} / \mathrm{s}$ & $\mathrm{LT}^{-1}$ \\
\hline \multicolumn{4}{|l|}{$\begin{array}{l}\text { Dependent } \\
\text { variable }\end{array}$} \\
\hline $\begin{array}{l}\text { a. Moisture } \\
\text { content }\end{array}$ & $\mathrm{MC}$ & - & - \\
\hline
\end{tabular}
that is dried pneumatically.

Table 1.Independent and dependent variables in dimensional analysis of moisture content of flour.

Source: Witdarko, (2016)

Based on those variables, there is functional relationship that is written below:

$$
\begin{gathered}
M C=f\left(\rho_{p r}, Q_{i}, T_{b o}, T_{u}, D_{p r}, \theta, V_{u}\right) \\
\pi=\rho_{p r}^{c 1} Q_{i}^{c 2} T_{b o}^{c 3} T_{u}^{c 4} D_{p r}^{c 5} \theta^{c 6} V_{u}^{c 7}
\end{gathered}
$$

There are 8 variables with 4 basic dimensions. Therefore, based on Buckhingham $\pi$ theory (Langgar,. $1967)$, there will be 4 dimensionless products $(\pi)$. By giving certain value for $\mathrm{c} 1, \mathrm{c} 3, \mathrm{c} 5$, and $\mathrm{c} 7$, there will be obtained:

$$
\pi_{1}=\mathrm{MC}
$$




$$
\begin{aligned}
& \pi_{\mathbf{2}}=\frac{\rho_{p r} \cdot D_{p r}^{3}}{Q_{\boldsymbol{i}} \cdot \boldsymbol{\theta}} \\
& \pi_{3}=\frac{T_{u}}{T_{b o}} \\
& \pi_{4}=\frac{V_{u} \cdot \theta}{D_{p r}}
\end{aligned}
$$

$\pi$ values are then arranged in the form of the following functional relationships:

$$
M C=C .\left(\frac{\rho_{p r} D_{p r}^{3}}{Q_{i} \cdot \theta}\right)^{a}\left(\frac{T_{u}}{T_{b o}}\right)^{b}\left(\frac{V_{u} \cdot \theta}{D_{p r}}\right)^{c}
$$

Constant $\mathrm{C}, \mathrm{a}, \mathrm{b}$, and $\mathrm{c}$ can be determined based on the data of research result carried out by changing the equation (10) in the form of log.

\subsection{Materials}

Material used in the research is $200 \mathrm{~kg}$ of white cassava. Cassava is then peeled and washed, then shred using grating machine. To reduce water in the grated cassava, it is pressed using hydraulic press machine. Every 1000 gram of grated cassava is pressed in $50 \mathrm{~kg} / \mathrm{cm}^{2}$ for 10 minutes. The solid grated cassava, after being pressed, is then decomposed manually into wet flour. The wet flour that passes 60 mesh sieve but left in 80 mesh sieve is used as the sample of material to be dried, and based on Stoess (1983)[7], the size of the flour is included in fine materials. The average moisture content of the sample of wet flour is $40-42 \% \mathrm{wb}$. Proceeding to next process, the sieved flour is dried using flash dryer that has been constructed through two processes.

\subsection{Equipment}

Fig. 1 shows pneumatic machine that has been constructed for this research. Heater source uses LPG gas with high-pressure burner and regulator that can be adjusted by setting the tap spin on the regulator and burner. Burner is placed inside a square furnace box with an adjustable opening airflow inlet. The adjustment of the dryer airflow velocity is conducted by adjusting the width of the furnace cover. The blower fan uses 735 watt of centrifugal sirocco blower that absorbs hot air and funnels it into the dryer pipe. Wet flour is put through feeding hopper equipped with a screw conveyor and 367-watt small blower as a supporting material. This feeding hopper is installed on the straight pipe above centrifugal blower. The dried material input rate can be adjusted by setting the spin speed of screw conveyor.

Drying process takes place along the dryer pipe line. Meanwhile, the separation of hot air, dust, and dry flour is carried out inside cyclone unit placed at the end of dryer pipe.

\subsection{Research Procedure}

The research is started by turning on the pneumatic dryer machine (flash dryer), then adjusting drying temperature, drying air flow velocity, and material input rate as specified. In this research, drying air temperature is varied for three levels, that is, $145^{\circ} \mathrm{C}$, $160^{\circ} \mathrm{C}$, and $175^{\circ} \mathrm{C}$. Likewise, the velocity of drying air flow is varied in three levels, that is, $17.12 \mathrm{~m} / \mathrm{s}, 18.10$ $\mathrm{m} / \mathrm{s}$, and $19.29 \mathrm{~m} / \mathrm{s}$. The dried material input rate is varied into $0.0371 \mathrm{~kg} / \mathrm{s}, 0.0509 \mathrm{~kg} / \mathrm{s}$, and $0.0616 \mathrm{~kg} / \mathrm{s}$. Other data needed for dimensional analysis such as $\rho_{\mathrm{pr}}$, $\mathrm{D}_{\mathrm{pr}}$, and $\mathrm{T}_{\text {bo }}$ are made stable into $1266 \mathrm{~kg} / \mathrm{m}^{3}, 0.2596$ $\mathrm{mm}$, and $30.43^{\circ} \mathrm{C}$ respectively. Meanwhile, $\theta$ (Drying time) is measured during the drying process. In the drying process of cycle 1 and 2 , temperature of environment is $29^{\circ} \mathrm{C}-30^{\circ} \mathrm{C}$, with relative humidity is $69 \%-70 \%$.

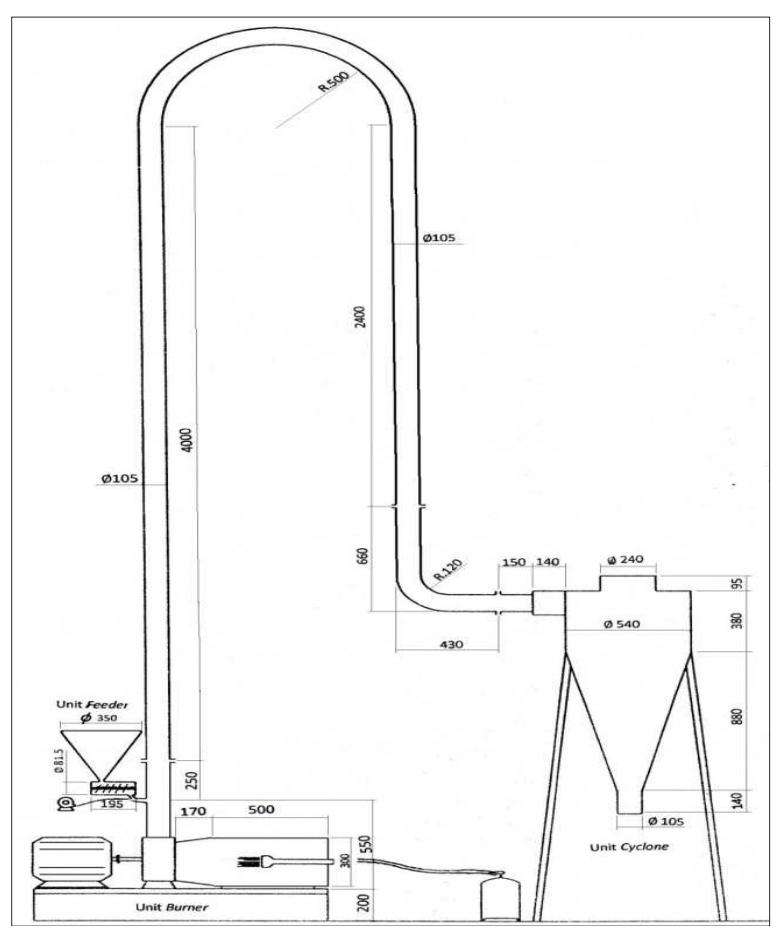

Fig. 1.Pneumatic mechanical dryer equipment (flash dryer)

\section{Result and Discussion}

Based on the data collected during the research, there will be dimensional analysis to determine constant values of equation that has been formulated. Using log form of equation (10), then constant values $\mathrm{C}, \mathrm{a}, \mathrm{b}$, and c obtained in cycle 1 is $5.7 \mathrm{E}-22,1.4085$, 2.2504 , and 5 , while cycle 2 is $2.3 \mathrm{E}-10,1.059,-4.808$, and 3.709 , so mathematic relationship between $\mathrm{MC}$ 
and drying process variables can be written in equation (11) and (12).

Drying cycle 1 is:

$=(5,794287 E-22) \cdot\left(\frac{\rho_{p r} \cdot D_{p r}^{3}}{Q_{i} \cdot \theta}\right)^{1,4085}\left(\frac{T_{u}}{T_{b o}}\right)^{-2,2504}\left(\frac{V_{u} \cdot \theta}{D_{p r}}\right)^{5,863}$

Drying cycle 2 is:

$$
\begin{gathered}
M C=(2,36831 E- \\
\text { 10). }\left(\frac{\rho_{p r} D_{p r}^{3}}{Q_{i} \cdot \theta}\right)^{1,059}\left(\frac{T_{u}}{T_{b o}}\right)^{-4,808}\left(\frac{V_{u} \cdot \theta}{D_{p r}}\right)^{3,709}
\end{gathered}
$$

Based on the equations, it is shown a relationship between each dimensionless products and MC of the dried material. Relationship of $\left(\frac{\rho_{p r} D_{p r}^{3}}{Q_{i} \theta}\right)$ towards MC where this research $\left(\frac{\rho_{p r} D_{p r}^{3}}{Q_{i} \theta}\right)$ is varied from 3E-08-5E08. It can be seen that the influence of $Q_{i}$ and $D_{p r}$ towards $\mathrm{MC}$ is opposite each other; if $\mathrm{Q}_{\mathrm{i}}$ goes up, MC goes down, or otherwise, if $\mathrm{D}_{\mathrm{pr}}$ goes up, MC goes up. Looking at the graph of Picture 2, it can be seen that the effect of $D_{\text {pr }}$ towards $\mathrm{MC}$ is bigger than the effect of $\mathrm{Q}_{\mathrm{i}}$ towards MC. Therefore, the relationship between $\left(\frac{\rho_{p r} D_{p r}^{3}}{Q_{i} \theta}\right)$ and $\mathrm{MC}$ forms linear line with positive slope, meaning that the greater the diameter of particles, the greater $\mathrm{MC}$ of flour obtained. In drying cycle 1, the drying process forms a linear line which is greater than drying cycle 2 .

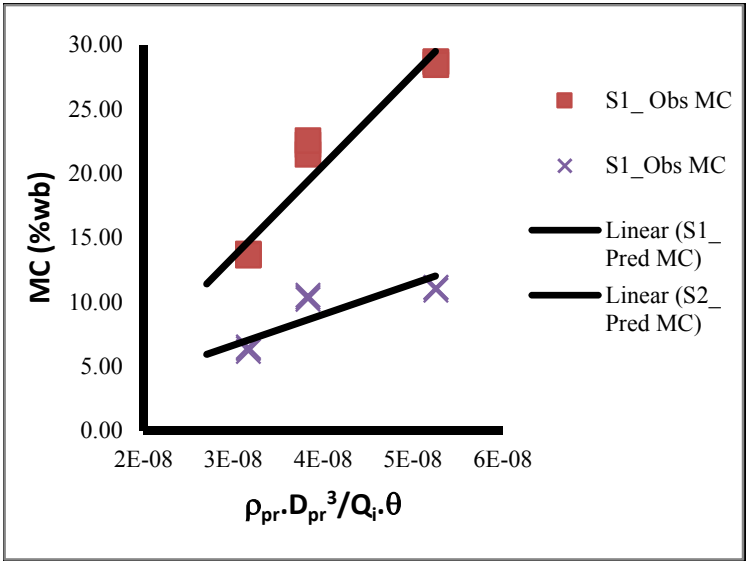

Fig.2.Graph of the relationship between $\rho_{\mathrm{pr}} \cdot \mathrm{D}_{\mathrm{pr}}{ }^{3} / \mathrm{Q}_{\mathrm{i}} \cdot \theta$ and $\mathrm{MC}$

The relationship of drying air temperature ration towards initial material temperature with content water of dried flour, which in this study, $\left(\frac{T_{u}}{T_{b o}}\right)$ is varied from 4.7139-5.6892 can be seen in Picture 3. In cycle 1 and 2 , drying shows that $\left(\frac{T_{u}}{T_{b o}}\right)$ ratio is getting bigger, which means that the difference of material and drying air is getting bigger. The greater the temperature difference between material and drying air, the more the heat transfer from air to material will increase. It is due to the fact that temperature difference is driving force of the heat transfer. The more the heat transfer increases, the bigger the ability to evaporate water from the material, so moisture content of the dried material decreased.

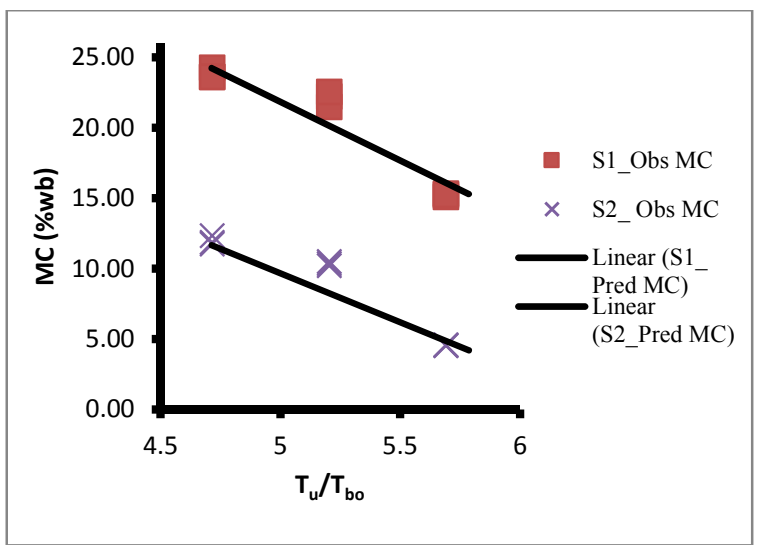

Fig 3.Graph of the relationship between $T_{u} / T_{b o}$ and $\mathrm{MC}$

Relationship between dimensionless product $\frac{\theta \cdot V_{u}}{D_{p r}}$ and MC can be seen in Picture 4, in which this research $\left(\frac{\theta \cdot V_{u}}{D_{p r}}\right)$ is varied from $750483.82-845609.40$. In drying cycle 1 , if diameter of the dried material particle and the drying time are stable, the rise of air flow rate will result in the increase of content water of the dried material. It is due to the rise of air flow velocity which results in the rise of residence time of material heating. In drying cycle 2 , if diameter of the dried material particle and the drying time are stable, the rise of air flow velocity will result in the rise of moisture content of the dried material, but the positive slop has tendency to increase low moisture content. 


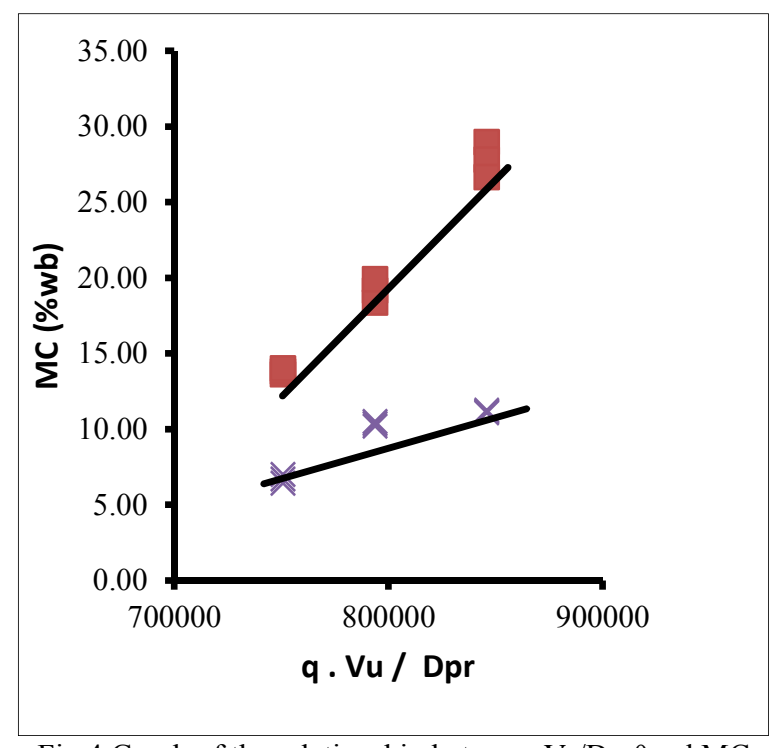

Fig 4.Graph of the relationship between $\mathrm{V}_{\mathrm{u}} / \mathrm{D}_{\mathrm{pr}}$. $\theta$ and $\mathrm{MC}$

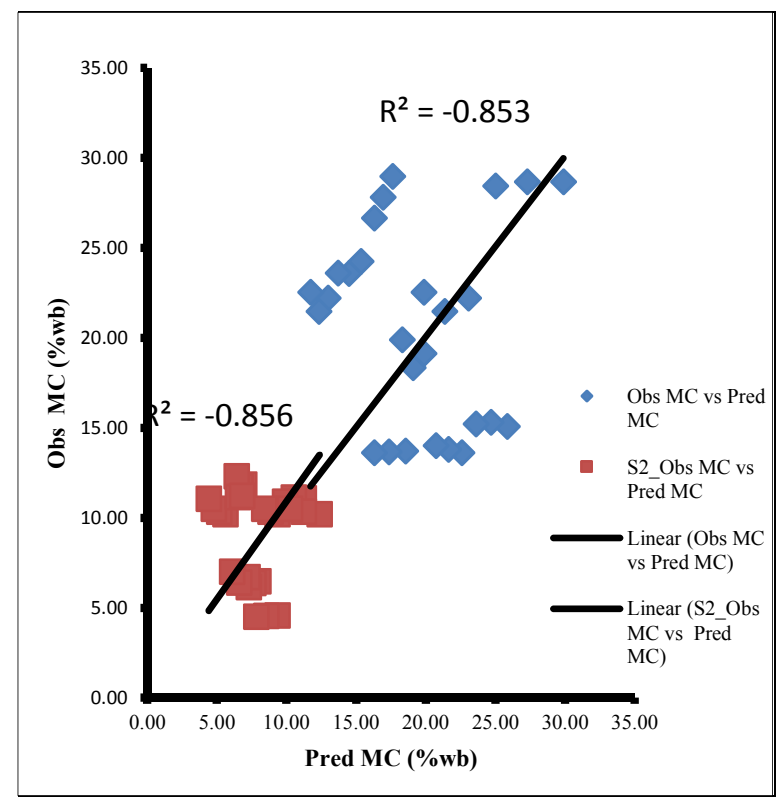

Fig 5.Graph of the relationship between prediction $\mathrm{MC}$ and observation MC

By using equation (11) and (12), calculation to determine $\mathrm{MC}$ value of dried material can be proceeded. Comparison between prediction $\mathrm{MC}$ value in equation (11) and (12) with $\mathrm{MC}$ value of flour that can be measured directly in environmental condition with temperature of $29^{\circ} \mathrm{C}$ and relative humidity of $70 \%$ can be seen in Picture 5. Based on the picture, it is shown that moisture content values of prediction result are able to predict MC value of the observation result, of which proximity can be seen from the relativelyhigh determination coefficient value (0.85). Based on the result, it is expected that equation (11) and (12) can be used to predict MC value of pneumatic-dried material well.

\section{Conclusion}

Based on the research result, it can be concluded that $\mathrm{MC}$ of pneumatic-dried flour is influenced by several factors such as $\rho_{p r}, Q_{i}, T_{b o}, T_{u}, D_{p r}$, and $\mathrm{V}_{\mathrm{u}}$.Mathematically, the relationship between variables with MC value of dried flour can be formulated by applying dimensional analysis in the form of functional relationship below:

Drying cycle 1:

$=(5,794287 E-22) \cdot\left(\frac{\rho_{p r} \cdot D_{p r}^{3}}{Q_{i} \cdot \theta}\right)^{1,4085}\left(\frac{T_{u}}{T_{b o}}\right)^{-2,2504}\left(\frac{V_{u} \cdot \theta}{D_{p r}}\right)^{5,863}$

Drying cycle 2:

$M C=(2,36831 E-10) \cdot\left(\frac{\rho_{p r} \cdot D_{p r}^{3}}{Q_{i} \cdot \theta}\right)^{1,059}\left(\frac{T_{u}}{T_{b o}}\right)^{-4,808}\left(\frac{V_{u} \cdot \theta}{D_{p r}}\right)^{3,709}$

Dimensionless product that influences moisture content most on the equations is $\left(\frac{T_{u}}{T_{b O}}\right)$. The equation is applied for value $\left(\frac{\rho_{p r} \cdot D_{p r}^{3}}{Q_{i} \cdot \theta}\right)$ of $3 \mathrm{E}-08-5 \mathrm{E}-08$, $\left(\frac{T_{u}}{T_{b o}}\right)$ of $4.7139-5.6892$, and $\left(\frac{V_{u \cdot \theta}}{D_{p r}}\right)$ of750483.82845609.40 .

\section{Acknowledgement}

The writer wants to thank to those who have given contribution to this research, especially to Dr. Ir. NursigitBintoro, M.Sc.

\section{References}

1. Afrianti, L.H. Teknologi Pengawetan Pangan. Penerbit Alfabeta,Bandung.(2005)

2. Badan Standardisasi Nasional. SNI 01-2997-1996, SNI tepung singkong (cassava flour).http://www.sisni.bsn.go.id/SNI01-29971996. (2012)

3. Bunyawanichakul, P., Walker, J.E., Sargison, J.E. and Doe, P.E.,Modelling and simulation of paddy grain (rice) drying in a simple pneumatic dryer. Journal of BiosystemsEngineering96,3 (2007)

4. Desrosier, N.W.,Teknologi Pengawetan Bahan. Edisi ketiga. Penerbit Universitas Indonesia, Jakarta.(2008)

5. Goula, A.M. and Adamopoulos, K.G., Spray drying of tomato pulp in dehumidified air: II. The effect on powder properties.Journal of Food Engineering,66(2005) 
6. Langhaar, H.L.,Dimensional Analysis and Theory of Models. A.I.T., Library, Jhon Wiley and Sons, Inc, New York (1967)

7. Stoess, H.A.J.R.P.E.,Pneumatic Conveying, $2^{\text {nd }}, A$ Wiley-Interscience Publication, John Wilay and Sons, New York(1983)

8. Zare, D., Ranjbaran, M., Niakousari, M. and Javidi, M.' Thin layer drying and equilibrium moisture content equations for canola (Brassica napus L.).Iran Agricultural Research 31,1 (2012)

9. Witdarko Y, Bintoro N, Suratmo B, Rahardjo B, Pemodelan Matematis Hubungan Kadar Air Tepung dengan variabel proses pada pengeringan mekanis tepung kasava menggunakan pneumatic dryer, Agritech,ISSN:0216-0455, 36,10(2016) 